\title{
USING HERZBERG THEORY TO DEVELOP THE EMPLOYEES' PERFORMANCE OF RAFHAN MAIZE INDUSTRY
}

\author{
Sumra Haleem Shaikh* \\ $\mathrm{PhD}$ Research Scholar, University of Sindh, Jamshoro, Pakistan
}

\begin{abstract}
Haseeb Shaikh
Engineer, Civil Department, Mehran University of Engineering and Technology, Jamshoro and Sr. Estimator Engineer at Riyadh Metro Project - Riyadh Saudia Arabia

\section{Sumair Shaikh}

Engineer, Mechanical Department, Quaid e Awam University of Engineering, Science and technology, Nawabshah, Pakistan

*Corresponding Author
\end{abstract}

\begin{abstract}
This study determine the impact of Herzberg two-factor theory on employees of Rafhan industry. The current paper applies Herzberg two-factor theory for improving the employees' performance. Seven point Likert scale is used for survey purpose. Descriptive statistics, Reliability test, Pearson correlation, Analysis Of Variance (ANOVA), $t$ test and multiple regression techniques are used for data analysis. Convenience non-probability sampling and random probability sampling are applied in this study. The results have shown that motivators (advancement, achievement, work itself, recognition and growth) and hygiene factors (company policy, work security, relationship with supervision, working condition, money and relationship with peers) of Herzberg two-factor theory are positively effects on employees' performance. This study provide much knowledge about Herzberg theory that create benefits to individual as well as for organization. This study suggested that motivators (advancement, achievement, work itself, recognition and growth) and hygiene factors (company policy, work security, relationship with supervision, working condition, money and relationship with peers) should be employed in Rafhan industry properly.
\end{abstract}

Key word: Employee performance, Herzberg's theory, Hygiene factors, Motivators, Rafhan Industry.

Cite this Article: Sumra Haleem Shaikh, Haseeb Shaikh, Sumair Shaikh, Using Herzberg Theory to Develop the Employees' Performance of Rafhan Maize Industry, International Journal of Management, 10 (3), 2019, pp. 1-7.

http://iaeme.com/Home/issue/IJM?Volume=10\&Issue=3 


\section{INTRODUCTION}

Factors of Herzberg theory are essential for improvement of performance for every organization (Nosraty et al., 2015). Rafhan Maize industry, is working as a team to make their customers relations good by providing best 'Halal' and safe food and services. Rafhan Maize industry keeps employees at their position for long period. Rafhan Maize industry also provide harmless and protected environment to their employees. Rafhan Maize industry controls Food Safety Threats and operate their operations in excellence ways to provide their customers qualitative product.

Employees are effective factor responsible for their performance and progress of organization therefore, employees should be motivated (Nosraty et al., 2015). Motivation motivates the employees for doing best work for achieving goals of organization (Nosraty et al., 2015). This study focused on Herzberg two-factor theory that categorized into two groups: Motivators and hygiene factors (Dartey-Baah, K., 2011).

\section{LITERATURE REVIEW}

Stoke (1999) defined motivation is a good way to motivate employees. When someone is not motivated, it means he/she does not feel good and relax at workplace. Secondly, for better performance, motivation factors plays an important role. Managers should apply motivation and hygiene factors in their organization for better productivity and sustainability of organization. According to Seligman (1995), the motivation function is maximizing satisfaction by minimizing pain physically. Miner et al., (1995) asserted that needs, drives and incentives are interacting elements of motivation.

Motivation is doing something as drinking water for reducing thirst or reading book to gain knowledge. Motivation is a way to arouse the performance by organic, emotive, societal and intellectual powers. Many companies make handsome policies for developing skills of employees. These policies are very helpful for boosting the performance of organization and for achieving sufficient output (Bhadoriya \& Chauhan, 2013).

Employees can be identified through organization goals and their contributions. Moorhead and Griffin (1998) asserted that management functions are properly implement with motivated employees. Emeka et al., (2015) asserted that high motivation of employees influenced by variety of factors as job security, employees' satisfaction, training and development, compensation, appraisals, positive feedback, intrinsic (intangible) rewards and extrinsic (tangible) rewards. Through motivation, employees do their best work even in strenuous circumstance and face the greasy challenges easily.

Dahlqvist and Matsson (2013) asserted that for higher performance of employees, motivation is an important aspect, which also retains them for longer period in organization and ultimately increases company's reputation. Employees are more satisfied through opportunities, good working condition, good policies, security of a job and loyal relations (Palaniammal, 2013).

Shahid (2012) summarized that employees' motivation is highly motivated by financial incentive, relationship with co-workers, promotional opportunities and employees' employment.

Bruzelius and Skarvad (2004) believed that intrinsic and extrinsic rewards make the employees' motivation high and they become professional which boosts company's worth. Employee's motivation helps in growth of organization as well as growth of individual. The rewards positively influence worker's performance and motivate them to boost their productivity by keeping in mind task fulfillment and goal achievement. Whiteley (2002) noted that higher motivation increases the employees' performance that gives the best outcomes. 
There are two aspects of Herzberg theory, motivators and hygiene factors (Stello, 2012). Current study supports to fill the gap in organizational behavior research. Earlier studies have found significant and positive results, in terms of employees' performance such as Bear et al., (2017), Parker et al., (2017) and Stella (2013). The research of Hur (2017) considered the influence of public sector managers' relation with their employees by applying Herzberg's theory and results determined the positive response among them. Matei and Abrudan (2016) also applied applications of Herzberg's two-factor theory to deliberate the relationship between motivations of employees with culture of organization. The results of Matei and Abrudan (2016) signified positive results that motivators are driven from intrinsic motivation, which gives positive response to employee performance whereas hygiene factors are driven from extrinsic elements, which eliminate the areas of dissatisfaction.

According to Herzberg (1974), moral spirits related to motivators such as advancement, achievement, work itself, recognition and growth. Whereas immoral or unpleasant feeling related to hygiene factors such as company policy, work security, supervision, money, working condition and relationship with peers (Dartey-Baah, and Amoako, 2011).

Good or superior feelings related to motivators (recognition, achievement, advancement, work itself and growth) whereas bad or awful feeling related to hygiene factors (job security, salary, work conditions, good relationship with coworkers, company policy and effective supervision) (Herzberg, 1959). In 1968, an article was published by Herzberg, which explained the way to enforce employees to do their job task. For this purpose KITA, terminology was used which meant to push the employees to do job completely which makes the job interesting but not motivating (Dartey-Baah and Amoako, 2011).

Two-factor theory argued that individuals are not motivated by lower-level needs (extrinsic or hygiene factors) only because hygiene factors do not motivate them but eliminate dissatisfaction for better performance. Top stage of requirements (intrinsic or motivation factors) should be given for motivating and improving employee's performance (Robbins, 2009; Ramlall, 2004).

According to Dahie et al., (2015), industrial employees can improve their individual and organizational performance by applying two-factor theory. Motivators and hygiene factors create the positive and significant relation with employee motivation (Edrak et al., 2013). Herzberg two-factor theory not only distinct the disputes of satisfaction and dissatisfaction but also explained the mode of two groups of intrinsic and extrinsic factors affect employees (Tan, 2013). Motivators and hygiene factors of Herzberg theory demonstrate the way to increase the productivity and improve skills of employees in efficient, operative and ordered way (Stello, 2012). Latham (2012) determined that the Herzberg two-factor theory mostly focused at specific necessities for their pleasure. Motivators cause increase in level of motivation whereas decrease in level of motivation cause the absence of hygiene factors (Ghafoor, 2012).

\section{SCOPE OF THE STUDY}

Current paper will provide vast information in educational work. Corporate managers and Government Policy Makers will use the results of this research. This paper will play a supportive role for researchers and professionals to recognize the dynamic and constructive relationship between motivators and hygiene factors with employees' performance.

\section{RESEARCH OBJECTIVES}

The research consists of following objectives:

- To evaluate the effects of motivation factors on employees' performance.

- To evaluate the effects of hygiene factors on employees' performance. 


\section{RESEARCH HYPOTHESES}

In this study, research hypotheses are:

- H1: Motivators significantly correlated with employees' performance.

- H2: Hygiene factors significantly correlated with employees' performance.

\section{RESEARCH METHODOLOGY}

For purpose of gathering and analyzing of data, research methodology plays an important role. The sample size is 455 to illustrate the target population. According to using online Raosoft sample size calculator, the sample size estimated is 384 (Raosoft, 2004). The data for this study is collected through questionnaires. Reliability test is conducted through SPSS version 20.0. ANOVA test, multiple regression techniques and independent $t$ test are used for analysis of data. Convenience non-probability sampling and random probability sampling are applied from which we can efficiently collect data. The data was collected from the Rafhan Maize Product Co. Ltd located at industrial areas of Kotri, Hyderabad, Sindh.

\section{ANALYSIS}

The results regarding descriptive statistics, internal consistency of variables and multiple regression used for current paper are following:

According to table 1, the descriptive statistics of motivators such as advancement, achievement, work itself, recognition and growth have mean more than 5 represented that these factors are close to degree that is agree level of statements. The individual Cronbach apha of intrinsic factors are statistically acceptable results whereas combined intrinsic factors showed statistically excellent results. The coefficient of determination ( $\mathrm{R}$ square) of motivators is 0.588 and hygiene factors is .575 . This model have explained the variance which described that five (motivators) independent variables have explained $58.8 \%$ of variation in (employees' performance) dependent variable. The results showed model is better fit which leads to less estimation error. The F-statistic of motivators (1237.69) at $0.000 \mathrm{p}$ value. According to rule of thumb for significant $p$ value is $<0.05$, results show model is best fit.

Table 1 of motivators of Rafhan industry

\begin{tabular}{|l|c|c|c|}
\hline & \multicolumn{3}{|c|}{ Rafhan Maize Industry } \\
\hline Intrinsic Factors & Mean & SD & Cronbach alpha \\
\hline Advancement & 5.518 & .68749 & .745 \\
\hline Achievement & 5.6201 & .69921 & .723 \\
\hline Work itself & 5.5113 & .71971 & .739 \\
\hline Recognition & 5.4948 & .82296 & .778 \\
\hline Growth & 5.4784 & .78645 & .798 \\
\hline Combined intrinsic factors & & & .970 \\
\hline R square & Adjusted R square & F value & P value \\
\hline .588 & .587 & 1237.69 & .000 \\
\hline
\end{tabular}

According to table 2, the descriptive statistics of hygiene factors such as company policy, work security, relationship with supervision, working condition, money and relationship with peers have mean more than 5 represented that these factors are close to degree that is agree level of statements. The individual Cronbach apha of extrinsic factors are statistically acceptable results whereas combined extrinsic factors showed statistically excellent results. The coefficient of determination ( $\mathrm{R}$ square) of hygiene factors is .575. This model have explained the variance which described that six (hygiene) independent variables have explained $57.5 \%$ of variation in (employees' performance) dependent variable. The results showed model is better fit which leads to less estimation error. The F-statistic of hygiene factors (978.760) at $0.000 \mathrm{p}$ 
value. According to rule of thumb for significant $p$ value is $<0.05$, results show model is best fit.

Table 2 of hygiene factors of Rafhan industry

\begin{tabular}{|l|c|c|c|}
\hline & \multicolumn{3}{|c|}{ Rafhan Maize Industry } \\
\hline Extrinsic Factors & Mean & SD & Cronbach alpha \\
\hline Company policy & 5.4455 & .82336 & .843 \\
\hline Work security & 5.4698 & .72941 & .796 \\
\hline Relationship with supervision & 5.4899 & .80285 & .798 \\
\hline Money & 5.4553 & .91971 & .884 \\
\hline Working condition & 5.4547 & .94785 & .857 \\
\hline Relationship with peers & 5.6741 & .66391 & .756 \\
\hline & & & P value \\
\hline R square & $\begin{array}{c}\text { Adjusted R } \\
\text { square }\end{array}$ & F value & .000 \\
\hline \multicolumn{1}{|c|}{.575} & .575 & 978.760 & \\
\hline
\end{tabular}

Rafhan Maize industry operate economical operations to secure the food from hazards and fulfil social responsibilities and making good customer relations.

\section{CONCLUSION}

Current paper illustrates the first impression in Rafhan Maize Industry, Kotri Sindh. No any type of research is occur, in Rafhan Maize Industry Kotri. This paper recognizes the degree level of certain motivational factors are influenced. The results from this study contribute that motivating employees and sustaining the productivity, might significantly facilitate employees. Moreover, present study also finds that motivational factors have strong positive impact on performance of workers working in Kotri from Hyderabad, Sindh. The management of Rafhan Maize Industry keeps the relationship healthy and for long period that create benefits for both organization and individuals, which ultimately raise to industry reputation to national as well as international level.

\section{ACKNOWLEDGEMENT}

I am very thankful to staff and teachers of IBA, University of Sindh, Jamshoro as well as staff of Rafhan Maize Industry.

\section{REFERENCES}

[1] Alderfer, C. P, An Empirical Test of a New Theory of Human Needs. Organizational Behavior \& Human Performance, 4(2), 1969, pp 142 - 175

[2] Bear, G. G., Slaughter, J. C., Mantz, L. S., \& Farley-Ripple, E., Rewards, praise, and punitive consequences: Relations with intrinsic and extrinsic motivation. Teaching and Teacher Education, 65, 2017, pp 10-20. https://doi.org/10.1016/j.date.2017.03.001

[3] Berl, R. L., \& Williamson, N. C, A review of the content theories of motivation as they apply to sales and sales management. American Business Review, 11, 1987, pp 53-64.

[4] Bhadoriya, S., \& Chauhan, S. S, A Critical Analysis on Intrinsic \& Extrinsic Factors of Motivation. IJMBS InternatIonal Journal of ManageMent \& BusIness studIes, 3(15), 2009, pp 2230-9519.

[5] Ravi Chandra G and Dr. A.B.Saraswathi, Impact of Performance Management System on Employee Performance- A Conceptual Frame Work for It Organizations, International Journal of Civil Engineering and Technology, 9(6), 2018, pp. 412-420. 
[6] Bruzelius, L., \& Skarvad, P.-H, Integrerad organisations lara. Lund: Student litteratur, 2004

[7] Cannizzaro, D., Stohl, M., Hasin, D. E, Intrinsic and extrinsic motivation predict treatment outcome in a sample of HIV+ drug user, 171,2017, 34.

[8] Dr. B Nagaraju and Pooja J, Impact of Salary on Employee Performance Empirical Evidence from Public and Private Sector Banks of Karnataka. International Journal of Marketing and Human Resource Management, 8(4), 2017, pp. 43-51.

[9] Dahie, A. M., Jim'ale, M. M., \& Ali, A. Y. S., Employee Motivation and Organizational Performance: Empirical Evidence from Secondary Schools in Mogadishu-Somalia. Academic Research International, 6(5), 2015, pp 69-83. https://doi.org/10.1037/00219010.67.3.341

[10] Dahlqvist, A., \& Matsson, A, The impact of extrinsic and intrinsic rewards on employees' motivation: A case study of an insurance company, 2013

[11] Dartey-Baah, K., \& Amoako, G. K, Application of Frederick Herzberg's Two-Factor theory in assessing and understanding employee motivation at work: a Ghanaian Perspective. European Journal of Business and Management, 3(9), 2011, pp 1-8. Retrieved from http://iiste.org/Journals/index.php/EJBM/article/view/642

[12] Feild, H. S., Holley, W. H., \& Armenakis, A. A, Graduate students' satisfaction with graduate education: Intrinsic versus extrinsic factors. Journal of Experimental Education, 43(2), 1974, pp 8-15. https://doi.org/10.1080/00220973.1974.10806312

[13] Stephen I. Dugguh and Jane I. Terzungwe, Knowledge Management and Employee Performance in the Brewery Industry: A Theoretical Examination of Consolidated Brewery Ltd, Makurdi-Nigeria, International Journal of Advanced Research in Management (IJARM), Volume 5, Issue 4, July- August (2014), pp. 48-59

[14] Edrak, B., Chan, B. Y.-F., Gharleghi, B., \& Thiam, K. S, The Effectiveness of Intrinsic and Extrinsic Motivations: A study of Malaysian Amway Company's Direct Sales Forces. International Journal of Business and Social Science, 4(9), 2013, pp 96-103.

[15] Ghafoor, M. M, Role of demographic characteristics on job satisfaction. Far East Research Centre, 6(1), 2012, pp 30-45. Retrieved from http://www.fareastjournals.com/files/FEJPBV6N1P3.pdf

[16] Government, T. I, Textiles Policy 2014-19, 2015, pp 1-22.

[17] Heathfield, S. M, Pay Attention to Employees to Create Employee Morale, 2013

[18] P. Bhuwaneshwari and Dr. M.B. Roopa, the Relationship between Job Resources and Employee Performance - The Mediating Role of Employee Engagement in Private Health Insurance Company. Journal of Management, 5(4), 2018, pp. 18-26.

[19] Herzberg, F, One More Time: How Do You Motivate Employees? Harvard Business Review, 65(5), 1968, pp 109-120.

[20] Herzberg, F. H., Mausner, B., \& Snyderman, B. S, The motivation to work. John Wiley and Sons, 1959.

[21] Herzberg, F, Motivation-hygiene profiles: Pinpointing what ails the organization. Organizational Dynamics, 3(2), 1974, pp 18-29. https://doi.org/10.1016/00902616(74)90007-2

[22] Dr. Nirzar Kulkarni. A Study on Relationship Between Employee Performance with High Performance HR System in Automobile Industry of Nagpur. Journal of Management, 4(2), 2017, pp. $74-80$

[23] Houston, D. J, Public-Service Motivation: A Multivariate Test. Journal of Public Administration Research and Theory, 10(4), 2000, pp 713-728.

https://doi.org/10.1093/oxfordjournals.jpart.a024288 
[24] Hur, Y, Testing Herzberg's Two-Factor Theory of Motivation in the Public Sector: Is it Applicable to Public Managers? Public Organization Review, 2017, pp 1-15. https://doi.org/10.1007/s11115-017-0379-1

[25] Kuvaas, B., Buch, R., Weibel, A., Dysvik, A., \& Nerstad, C. G. L, Do intrinsic and extrinsic motivation relate differently to employee outcomes? Journal of Economic Psychology, 61, 2017, pp 244-258. https://doi.org/10.1016/j.joep.2017.05.004

[26] Latham, G. P, Work Motivation: History, Theory, Research, and Practice. Sage

Publications Inc, 337. Retrieved from

http://books.google.com/books?id=0SoXpZXBrXYC\&pgis=1, 2012.

[27] Matei, M.-C., \& Abrudan, M.-M, Adapting Herzberg's Two Factor Theory to the Cultural Context of Romania. Procedia - Social and Behavioral Sciences, 221, 2016, pp 95-104. https://doi.org/10.1016/j.sbspro.2016.05.094

[28] Nosraty, S., Khosravipour, B., Monavvarifard, F., Hamidi, F., Salehi, L, Analyzing the role of motivation factors in Herzberg's theory on teachers's job satisfaction (Case study: Elementary schools in Talesh city), 3 (1), 2015, pp 87-92

[29] Parker, S. K., Morgeson, F. P., \& Johns, G, One Hundred Years of Work Design Research : Looking Back and Looking Forward, 102(3), 2017, pp 403-420.

[30] Rahman, K.-U., Akhter, W., \& Khan, S. U, Factors affecting employee job satisfaction: A comparative study of conventional and Islamic insurance. Cogent Business \& Management, 4(1), 2017, pp 1 - 15,. https://doi.org/10.1080/23311975.2016.1273082

[31] Ramlall, S, A Review of Employee Motivation Theories and their Implications for Employee Retention and their Implications for Employee Retention within Organisations. Journal of American Academy of Business, 5(1/2),2004, pp 52-63. https://doi.org/10.1063/1.2053360

[32] Robbins, S. P, Organizational behavior. Social Psychology: Handbook of Basic Principles., 2nd Ed., 913-939. Retrieved from http://ovidsp.ovid.com/ovidweb.cgi?T $=J S \& P A G E=$ reference $\& D=$ psyc $5 \& N E W S=N \& A N$ $=2007-11239-040,2009$

[33] Sadri, G., \& Bowen, R. C, Meeting employee requirements: Maslow's hierarchy of needs is still a reliable guide to motivating staff. Industrial Engineer: IE, 43(10), 2011, pp 44-48. https://doi.org/10.1126/science.212.4500.1214-b

[34] Shahid, M. N, Work Stress and Employee Performance in Banking Sector Evidence from District Faisalabad, Pakistan. Asian Journal of Business and Management Sciences, 1(7), 1998, pp 38-47.

[35] S. Saraswathi, A Study on Factors that Motivate IT and Non-IT Sector Employees: A Comparison. International Journal of Research in Computer Application and Management, Vol. 1 (2), 2011, pp 72-77.

[36] Stella, O, Motivation and Work Performance: Complexities in Achieving Good Performance Outcomes; A Study Focusing on Motivation Measures and Improving Workers Performance in Kitgum District Local Government. Istitute of Social Studies, (December),2008, pp 1-83. https://doi.org/10.1111/j.2044-8295.1969.tb01226.x

[37] Stello, C. M, Herzberg's Two-Factor Theory of Job Satisfaction: An Integrative Literature Review. Herzberg's Two-Factor Theory of Job Satisfaction, 32, 2014, https://doi.org/10.7537/marslsj140517.03.Keywords

[38] Weihrich H, \& Koontz H, Management : a global perspective, 600, 2001. 